\title{
SATISFACTION LEVEL OF PASSENGERS, SERVICE \& FACILITY OF KMP DHARMA BAHARI SUMEKAR III BY IPA AND CSI METHODS
}

\author{
Kurnia Hadi Putra ${ }^{1}$, Ita Suhermin Ingsih ${ }^{2}$, Bambang Wahyudi ${ }^{3}$ \\ ${ }^{1,3}$ Civil Engineering Department, Institut Teknologi Adhi Tama Surabaya, Indonesia \\ ${ }^{2}$ Civil Engineering Department, University of Islam Malang, Indonesia \\ e-mail: kurnia_putra@itats.ac.id
}

\begin{abstract}
Transport intends to ease the movement from one place to another. KMP Dharma Bahari Sumekar III belongs to one of transport facilities operated at Kalianget Port in Sumenep.This research aimed at investigating the satisfaction level of passengers taking KMP Dharma Bahari Sumekar III by implementing the methods of Importance Performance Analysis (IPA) and Customer Satisfaction Index (CSI). The research result indicated several essential attributes i.e. Quadrant II (toilet cleanliness in KMP Dharma Bahari Sumekar III and facility convenience for passengers in KMP Dharma Bahari Sumekar III and Quadrant II (safety in KMP Dharma Bahari Sumekar III, cleanliness in KMP Dharma Bahari III, the ability of officer in KMP Dharma Bahari Sumekar III to respond fast the emergent problems and be responsible on the safety and cozines of passengers). Meanwhile, the result of CSI method obtained $71,47 \%$.
\end{abstract}

Keywords: IPA, CSI, Passenger Satisfaction, Ship

\section{Introduction}

Transportation is the movement of people or goods, in this case through the media of vehicles driven by human power or machine power consisting of land, sea and air transportation. Meanwhile, according to Salim (2000), transportation is the movement of goods or passengers from one place to another. In an economic activity that connects islands to one another and continues to run smoothly, sea transportation is needed. Economic growth in underdeveloped areas as well as in developing areas, especially in areas consisting of islands and in areas adjacent to the sea, can be helped by sea transportation.

The growth of literature in the field of quality of service in the public transport (PT) sector shows increasing concern for a better understanding of the factor affecting service quality (SQ) in PT organization and companies [1].

One of the islands scattered in the Sumenep Regency area, namely Sapudi Island which is the second largest island after Kangean Island which also has the largest population among the islands in Sumenep Regency. In this case, of course, the movement of the population will not be separated from sea transportation. Ferry ports are vital when it comes to distribution of goods or people from one place to another. Because ferry ports are places where people shift, port areas are strategic places to extend businesses [2]. One of the modes of transportation that operates for the route of Kalianget Sumenep Port and Tarebung Sapudi Port is KMP Dharma Sumekar III. KMP Dharma Bhari Sumekar III is one of the ships owned by the Sumenep Regency Government which operates with routes including Kalianget Port, Sapudi Island, Raas Island, Kangean Island, Sapeken Island, Pagerungan Besar Island and Tanjung Wangi. The addition of this means of sea transportation has become the hope of the islanders for the last few years [3].

By the need for transportation services, in this case with the route of Kalianget Sumenep Port - Tarebung Sapudi Port, of course, sea transportation service users will definitely need an operating sea transportation fleet. Here KMP Dharma Bahari Sumekar III, which is one of the 
transportations that operate in the Kalianget Port area of Sumenep, is also an option for ship passengers who want to travel between islands. Apart from that, there are several problems that occur in the form of services provided by transportation service providers and services obtained by transportation users. Problems that arise such as travel time which is still considered insufficient, ticket prices are still considered expensive for passengers and some facilities for passengers which are considered not to be considered good by passengers. To know the level of service, the level of service quality cannot be judged from the point of view company but must be viewed from the customer's point of view [4].

\section{Material and Method}

The following are the stages carried out in study:

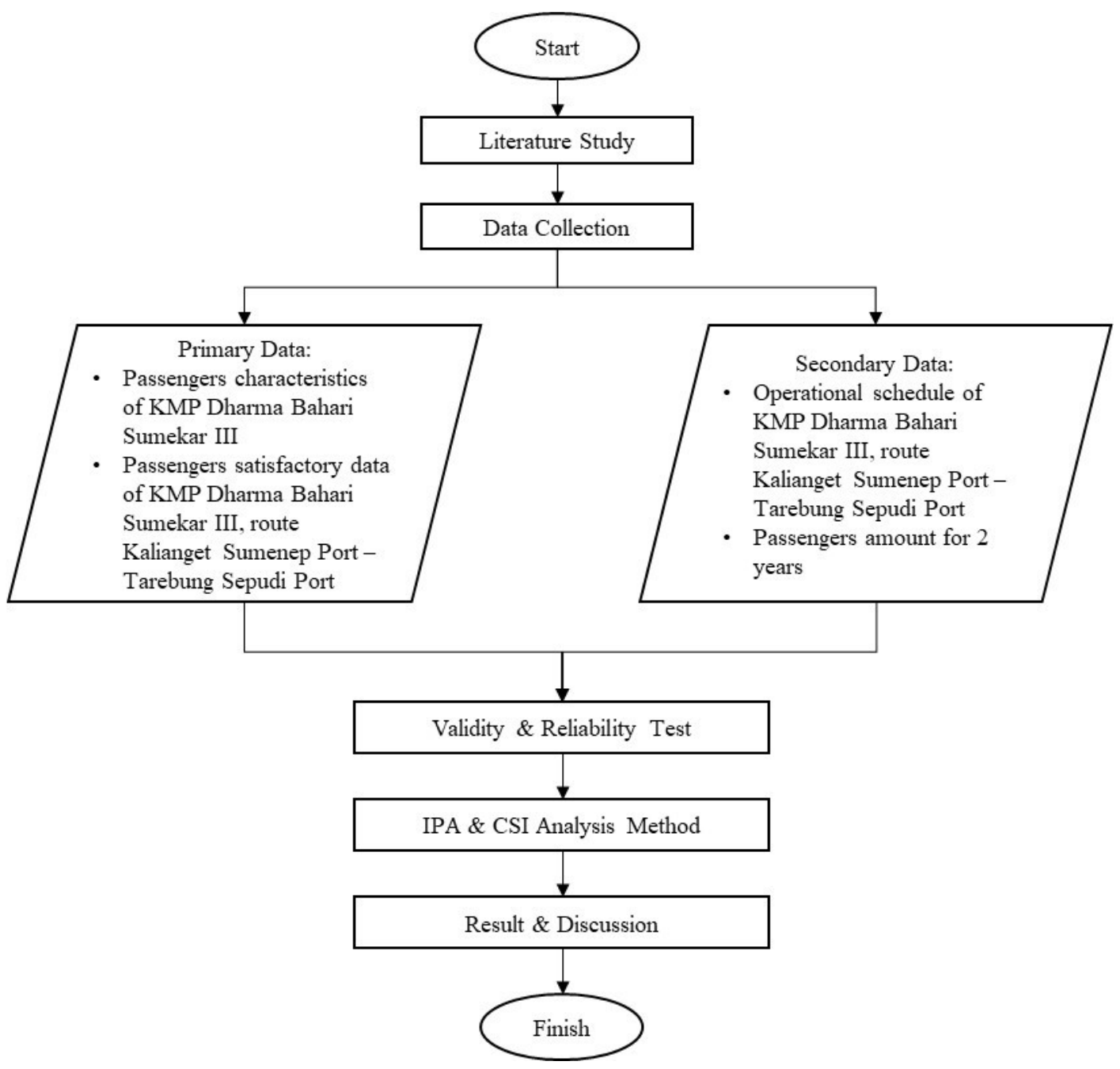

Figure 1. Steps of Research

KMP Dharma Bahari III has routes covering Kalianget Port, Sapudi Island, Raas Island, Kangean Island, Sapeken Island, Pagerungan Besar Island and Tanjung Wangi. In this study, the distribution of questionnaires was also carried out at KMP Dharma Bahari Sumekar III during the trip with the Kalianget Port Sumenep - Tarebung Sapudi Port route, with the target population being passengers, whose route can be seen in Figure 2 below. 


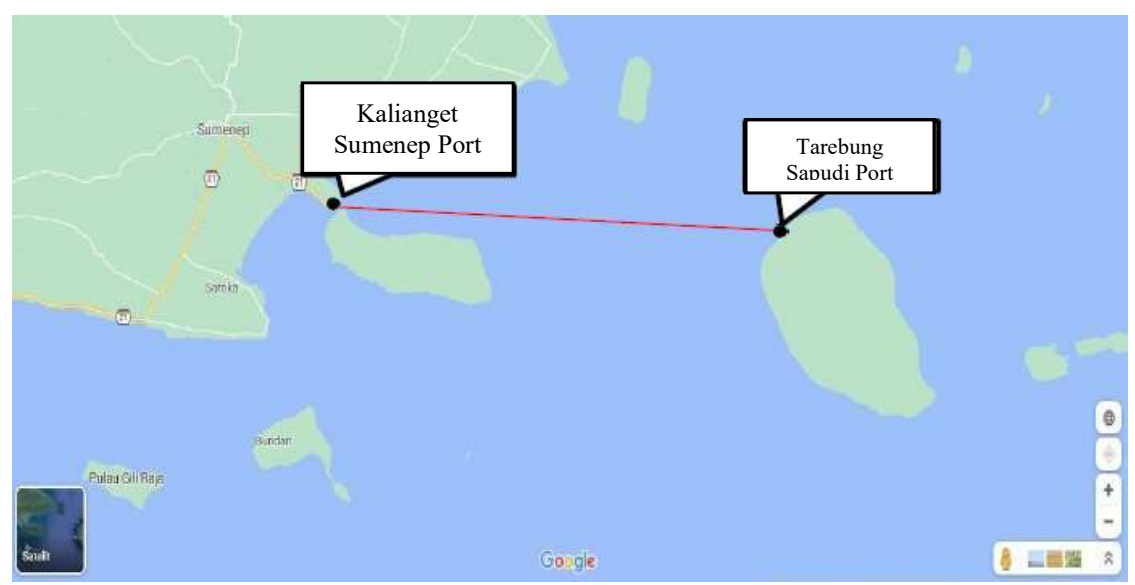

Figure 2. Route of KMP Dharma Bahari Sumekar III

\subsection{Data Collection}

In compiling a research, data collection is one of the important things to do with the aim of obtaining all the information needed to achieve a goal of the research itself. In this study there are two sources of data obtained by researchers, namely primary data and secondary data.

a. Primary Data

In primary data, the authors distributed questionnaires to passengers of KMP Dharma Bahari Sumekar III with the travel route taken from the Kalianget Port Sumenep - Tarebung Sapudi Port according to the operational hours of KMP Dharma Bahari Sumekar III with the aim of obtaining data on characteristics of passengers and data on passenger satisfaction. using the services of the KMP Dharma Bahari Sumekar III.

b. Secondary Data

In secondary data, the authors obtained the necessary data from the management of KMP Dharma Bahari Sumekar III, in the form of the operational schedule of KMP Dharma Bahari Sumekar III as well as data on the number of passengers in the last 2 years who used the services of the transportation to obtain data that would later be used when carrying out the process of collecting data and samples during research.

\subsection{Data Analysis}

\section{a. IPA (Importance Performance Analysis)}

Importance-performance analysis (IPA) is a common and accepted method used by service industries to improve their service and therefore increase customer satisfaction [5]. And also, Importance-performance analysis (IPA) has been widely used to examine the relationship between importance, performance, and overall satisfaction in tourism destinations [6]. Importance-performance analysis (IPA) is practical and useful method, that can help policymakers to identify service/product elements which allocation of resources could contribute to higher satisfaction of users [7]. In several research, Importance Performance Analysis (IPA) in this study successfully identified each attribute on customer satisfaction [8]. Processing of data that has been obtained from distributing questionnaires is then processed using the IPA (Importance Performance Analysis) method with the following steps.

1) Determine the level of conformity between the level of importance and the level of performance at KMP Dharma Bahari Sumekar III based on the comparison of the value of performance with the value of importance.

2) Calculate the average level of performance and level of importance.

3) Calculate the average of all attributes of performance level and level of importance which will later be used as limits on the Cartesian diagram. 
4) Mapping into a Cartesian diagram for the service aspects represented by the question items on the questionnaire which should be improved and which ones should not be improved.

\section{b. CSI (Customer Satisfaction Index)}

Satisfaction is the level of one's feelings after comparing the performance or results that he felt with his expectations [9]. Customer satisfaction index models have been developed in many countries, including Indonesia. Those models were commonly not focused on the socioeconomic status (SES) of the customer [10]. The data that has been obtained from the questionnaire is collected and processed so that it can be used as input data in the further analysis process which in this case is the CSI (Customer Satisfaction Index) method. CSI (Customer Satisfaction Index) is a method to calculate the level of customer satisfaction with the services provided by a company. In this CSI method, the measure used to express passenger satisfaction can be seen in the CSI criteria with categories stating the level of Very Satisfied to Dissatisfied.

In analysing the data obtained using this CSI method, there are several stages carried out, there are:

1) Entering the attributes in the questionnaire into the Attributes column.

2) Entering the average of the results of the questionnaire data that has been calculated into the column of importance (I) and satisfaction (P).

3) Adding up all values in the importance column (I), to be the total value of importance (Y).

4) Multiplying the value between the column of importance (I) with satisfaction (P) to find the score with the symbol (S), becoming the total score symbolized by the symbol (T).

\section{Result and Discussion}

\subsection{Importance Performance Analysis (IPA)}

The Importance Performance Analysis (IPA) method aims to determine which aspects of the service represented by the question items on the questionnaire should be improved and which ones should not be improved. The following is a Cartesian Importance Performance Analysis (IPA) diagram to describe service aspects at KMP Dharma Bahari Sumekar III which can be seen in Figure 3.

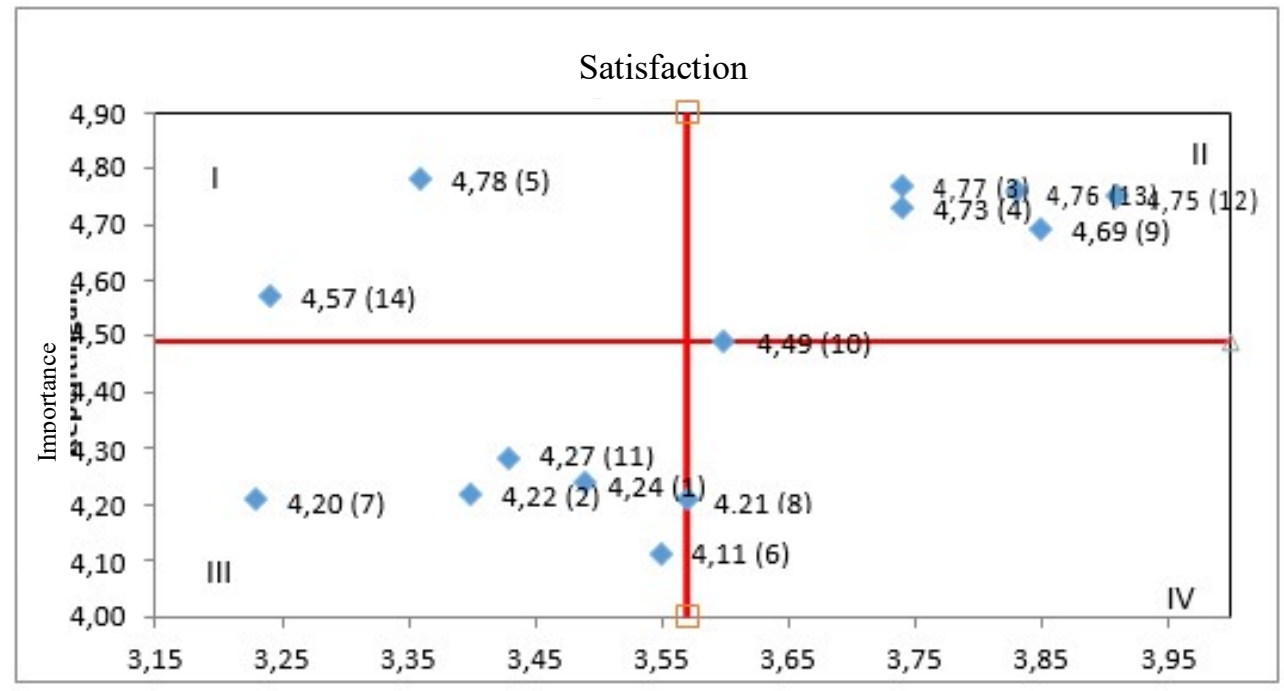

Figure 3. IPA Cartesian Diagram KMP Dharma Bahari Sumekar III 
Description of the assessment pattern:

1. Travel time

2. Cost

3. Safety inside of KMP Dharma Bahari Sumekar III

4. Cleanliness inside of KMP Dharma Bahari Sumekar III

5. Toilet cleanliness of KMP Dharma Bahari Sumekar III

6. Neatness of the officers of KMP Dharma Bahari Sumekar III

7. Accuracy of departure and arrival time

8. Friendly service and always ready to help

9. The ability of KMP Dharma Bahari Sumekar III officers to respond quickly to problems that occure.

10. The ability of KMP Dharma Bahari Sumekar III officers to respond quickly to complaints submitted by passengers

11. Polite and friendly service

12. Guarantee of service security in KMP Dharma Bahari Sumekar III

13. Responsible for the safety and comfort of passengers

14. Comfort of passenger facilities in KMP Dharma Bahari Sumekar III

Each of the quadrants describes a different state. This mapping based on the level of importance and performance makes it possible for KMP Dharma Bahari Sumekar III to make improvements to attributes that are considered important by service users.

1) Quadrant I (Main Priority)

In this position, when viewed from the interests of service users, product attributes are at a high level. However, when viewed from the level of satisfaction, service users feel low satisfaction so that service users want an improvement in the service as soon as possible. Companies should make efforts to increase service user satisfaction, which means that these attributes need to be managed and improved thoroughly and continuously so that service user satisfaction can be met. There are 2 attributes included in quadrant I, namely the cleanliness of the toilets of KMP Dharma Bahari Sumekar III and the comfort of passenger facilities in KMP Dharma Sumekar III. These service users feel that these two attributes are important, but in fact both of these attributes are still in line with the expectations of service users, so these two attributes need to be improved.

2) Quadrant II (Keep Achievement)

This position when viewed from the interests of service users, product attributes are at a high level. When viewed from the level of satisfaction, consumers also feel a high level as well. This makes the company to maintain its achievements, without making improvements because these attributes have attracted consumers but need to be maintained with good management as well. There are 5 attributes included in quadrant II, namely Security in KMP Dharma Bahari Sumekar III, Cleanliness in KMP Dharma Bahari Sumekar III, the ability of KMP Dharma Bahari Sumekar III officers to respond quickly to problems that arise, guarantee service security in KMP Dharma Bahari Sumekar III, and is responsible for the safety and comfort of passengers.

3) Quadrant III (Low Priority)

When viewed from the interests of service users, product attributes are considered less important, where service user satisfaction and performance of these attributes are also low. This indicates that the attributes included in quadrant III are less important, and for service providers, they are still being carried out or still given to service users, but with normal performance or nothing special because service users also consider these attributes This is also less important for service users. 
Some of the attributes included in quadrant III in this study are travel time, fares / fees, neatness of the officers of KMP Dharma Bahari Sumekar III, accuracy of departure and arrival time and courteous and friendly service.

4) Quadrant IV (Exaggerated)

When viewed from the interests of service users, product attributes are considered less important, but in practice they have a high level of performance. In other words, the level of performance is greater than user expectations or satisfaction, and in this case the service provider continues to offer or provide these services to service users.

In this quadrant there are 2 attributes, namely friendly service and an attitude that is always ready to help and the ability of KMP Dharma Bahari Sumekar III officers to respond quickly to complaints submitted by passengers.

\subsection{Analysis of Customer Satisfaction Index (CSI)}

The following are the results of calculations by the author based on data that has been obtained and processed from the research site using tools that can be seen in Table 1.

Table 1. Calculation of Customer Satisfaction Index (CSI)

\begin{tabular}{|c|c|c|c|c|}
\hline \multirow{3}{*}{ No. } & \multirow{3}{*}{ Question } & Importance & Satisfaction & \multirow{2}{*}{ Score } \\
\hline & & (I) & $(\mathrm{P})$ & \\
\hline & & scale $1-5$ & scale $1-5$ & $\begin{array}{l}\mathrm{S}=\mathrm{I} X \\
\mathrm{P}\end{array}$ \\
\hline 1 & Travel time & 4,24 & 3,49 & 14,8 \\
\hline 2 & Cost & 4,22 & 3,4 & 14,35 \\
\hline 3 & Safety inside of KMP Dharma Bahari Sumekar III & 4,73 & 3,74 & 17,69 \\
\hline 4 & $\begin{array}{l}\text { Cleanliness inside of KMP Dharma Bahari } \\
\text { Sumekar III }\end{array}$ & 4,77 & 3,74 & 17,84 \\
\hline 5 & $\begin{array}{l}\text { Toilet cleanliness of KMP Dharma Bahari } \\
\text { Sumekar III }\end{array}$ & 4,78 & 3,36 & 16,06 \\
\hline 6 & $\begin{array}{l}\text { Neatness of the officers of KMP Dharma Bahari } \\
\text { Sumekar III }\end{array}$ & 4,11 & 3,55 & 14,59 \\
\hline 7 & Accuracy of departure and arrival time & 4,2 & 3,23 & 13,57 \\
\hline 8 & Friendly service and always ready to help & 4,21 & 3,57 & 15,03 \\
\hline 9 & $\begin{array}{l}\text { The ability of KMP Dharma Bahari Sumekar III } \\
\text { officers to respond quickly to problems that } \\
\text { occure }\end{array}$ & 4,69 & 3,85 & 18,06 \\
\hline 10 & $\begin{array}{l}\text { The ability of KMP Dharma Bahari Sumekar III } \\
\text { officers to respond quickly to complaints } \\
\text { submitted by passengers }\end{array}$ & 4,49 & 3,6 & 16,16 \\
\hline 11 & Polite and friendly service & 4,27 & 3,43 & 14,65 \\
\hline 12 & $\begin{array}{l}\text { Guarantee of service security in KMP Dharma } \\
\text { Bahari Sumekar III }\end{array}$ & 4,75 & 3,91 & 18,57 \\
\hline 13 & $\begin{array}{l}\text { Responsible for the safety and comfort of } \\
\text { passengers }\end{array}$ & 4,76 & 3,83 & 18,23 \\
\hline 14 & $\begin{array}{l}\text { Comfort of passenger facilities in KMP Dharma } \\
\text { Bahari Sumekar III }\end{array}$ & 4,57 & 3,23 & 14,76 \\
\hline & Total & 62,81 & 3,57 & 224,47 \\
\hline
\end{tabular}


From the data analysis, it is known that the average perceived service quality (I) and the expected service quality $(\mathrm{P})$ on the results of the questionnaire distribution are then searched for the score (S) by multiplying the average perceived service quality (I) and expected (P). Then add up the perceived service quality column (I) and add up the score column (S). After obtaining each amount, it is calculated using the formula:

$$
\begin{aligned}
C S I & =\frac{T}{5 Y} \times 100 \% \\
& =\frac{224,47}{5(62,81)} \times 100 \\
& =71,47 \text { (Satisfy) }
\end{aligned}
$$

The result value of the level of customer satisfaction is $71.47 \%$. The criteria for the level of customer satisfaction are in the satisfied category. If it is related to the results of calculations using the IPA method and looking at the results of the Cartesian diagram, the CSI value cannot reach $100 \%$ which is probably due to the presence of several attributes in quadrant I which is a top priority that can be improved again so that it becomes better, as well as in quadrant III which become the second priority in terms of performance improvement. The attributes contained in quadrant II must also be maintained and maintained so that the quality of their performance does not decrease, and for attributes that are in quadrant IV which are excessive attributes, it can be used as a way to cover the shortcomings that exist in KMP Dharma Bahari Sumekar III.

\section{Conclusions}

From the research that has been done, the following conclusions can be drawn:

1) Based on the results of a survey with 384 respondents, the characteristics of the passengers are as follows: the highest passenger age is 21-40 years old, totaling 155 people with a percentage of $40.4 \%$. The sex of the most passengers was male, amounting to 198 people with a percentage of $51.6 \%$. For the most jobs are civil servants as many as 121 people and the percentage is $31.5 \%$. The highest income is at Rp. $1,000,000-3,000,000$ as many as 212 people with a percentage of $55.2 \%$. Most travel destinations are working with 165 people and the percentage is $43 \%$. Meanwhile, the most frequent passenger travel intensity was $>5 \mathrm{x}$, which amounted to 184 people and $47.9 \%$.

2) Based on the data in the Cartesian diagram for IPA, the attributes that are considered important by passengers who use the services of KMP Dharma Bahari Sumekar III are attributes that are located in quadrant I, namely the attributes of cleanliness of the toilets of KMP Dharma Bahari Sumekar III and the comfort of passenger facilities in KMP Dharma Sumekar III, and quadrant II are the attributes of Security in KMP Dharma Bahari Sumekar III, Cleanliness in KMP Dharma Bahari Sumekar III, the ability of KMP Dharma Bahari Sumekar III officers to respond quickly to problems that arise, Guarantee service security in KMP Dharma Bahari Sumekar III, and Responsible for the safety and comfort of passengers. Based on the results of the Cartesian diagram, it was also found that several question attributes related to some of the problems that occurred, which is in line with some problems that arise or some facilities that are still not good for passengers.

3) Meanwhile, based on the results of calculations using the CSI method for the satisfaction value of the passengers of KMP Dharma Bahari Sumekar III, the result is $71.46 \%$, the satisfaction level of the passengers is included in the Satisfied category. 
4) Based on the results obtained, several facilities that can be improved or improved are travel time, fares / fees, neatness of the officers of KMP Dharma Bahari Sumekar III, accuracy of departure and arrival time and courteous and friendly service.

\section{References}

[1] J. d. Oña and R. d. Oña, "Quality of service in public transport based on customer satisfaction surveys: A review and assessment of methodological approaches," Transportation(Science, vol. DOI: 10.1287/trsc.2014.0544, 2014.

[2] Y. A. Malik, B. H. Iskandar and Kirbrandoko, "An Analysis of Passengers' Segmentation And Satisfaction Regarding The Development of The Miscellaneous Services Business of Merak Ferry Port," International Journal of Scientific and Research Publications, vol. 7, no. 3, pp. 351-359, 2017.

[3] Arifin/Nurul, "Portal Madura," 31 October 2018. [Online]. Available: https://portalmadura.com/kmp-dbs-iii-resmi-dioperasikan-ini-harapan-warga-kepulauan171054/. [Accessed 20 January 2021].

[4] M. D. Darus and K. Mahalli, "Analisis Tingkat Kepuasan Penumpang Terhadap Kualitas Pelayanan Di Bandar Udara Internasional Kualanamu," Jurnal Ekonomi dan Keuangan, vol. 3, no. 6, pp. 408-420, 2015.

[5] A. R. Valencia, D. R. Satizábal and D. Paris, "Importance-Performance Analysis in Public Transportation: Methodological Revision for Practical Implementation," Transportation Research Record Journal of the Transportation Research Board (TRANSPORT RES REC), vol. DOI: 10.1177/0361198118825125, 2019.

[6] J. Deng and C. D. Pierskalla, "Linking Importance-Performance Analysis,Satisfaction, and Loyalty: A Study of Savannah, GA," sustainability, vol. 10, no. 704, pp. 1-17, 2018.

[7] Š. Ormanović, A. Ćirić, M. Talović, H. Alić, E. Jelešković and D. Čaušević, "ImportancePerformance Analysis: Different Approaches," Acta Kinesiologica, vol. 11, no. 2, pp. 58-66, 2017.

[8] O. S. Tjitrohartoko and T. G. Saraswati, "Applying Importance Performance Analysis to Assess Customer Satisfaction: Mass Rapid Transportation in Indonesia," International Journal of Management, Entrepreneurship, Social Science andHumanities (IJMESH), vol. 3, no. 1, pp. $16-23,2020$.

[9] A. I. Rifai and Y. I. Fajriliani, "Analysis of Passenger Satisfaction Level of Service And Facilities of Electric Rail Train(KRL) Commuter Line Route Bekasi -Manggarai," Journal of World Conference JWC, vol. 2, no. 2, pp. 126-135, 2020.

[10] B. Setiawan, "Customer Satisfaction Index Model on Three Level Of Socioeconomic Status In Bogor Case Study: Customer Satisfaction on Branded Cooking Oil Product," ASEAN MARKETING JOURNAL, vol. 6, no. 1, pp. 15-24, 2014. 